\title{
Membangun Literasi Budaya Lokal Kepada Generasi Z Melalui Tradisi Weh-Wehan di Kecamatan Kaliwungu, Kabupaten Kendal
}

Building Local Culture Literacy to Generation Z through the

Weh-Wehan Tradtition in the Kaliwungu District of Kendal

\section{Viro Dharma Saputra}

Universitas Selamat Sri

Alamat: Jl. Soekarno-Hatta Km. 03, Kendal, Jawa Tengah

viiro.dharma@gmail.com

Dikirim: 4 Mei 2020, Direvisi: 21 Mei 2020, Diterima: 16 Juni 2020, Terbit: 18 Juni 2020

Sitasi: Saputra, V.S. (2020). Membangun Literasi Budaya Lokal kepada Generasi Z melalui

Tradisi Weh-Wehan di Kecamatan Kaliwungu, Kabupaten Kendal. PRoMEDIA. Volume 6 (1), Juni 2020, hal 155- hal 175

\begin{abstract}
The purpose of this study is to introduce the local culture in the form of the weh-wehan tradition. The tradition of welcoming the Prophet's birthday and taking place once a year attracts a lot of attention. Many of the $Z$ generation born in the 1995-2010 range were affected by the use of smartphones to access the latest news and did not pay attention to the existing local culture. This influence is great for the threat of cultural literacy transmitted from gen $X$ to generation $Z$. Aims to know the cultural literacy carried out by generation $Z$ and the impact of this tradition on generation $Z$. Using descriptive qualitative and snowball sampling, as informants are local figures representing generation $x$ by the Chair of IPNU, and Gen $Z$ was represented by the youth leaders and students. Based on the results obtained that to build local wisdom, can invite generation $z$ to participate together through the weh-wehan tradition which only takes place once a year in the celebration of the Birthday of the Prophet. It aims to introduce cross-cultural culture that must be held fast to the current generation $z$.
\end{abstract}


PROMEDIA (PUBLIC RELATION DAN MEDIA KOMUNIKASI) ISSN 2460-9633

Volume Ke-6 No. 1, 2020, Saputra, Membangun Literasi, hal 155 - hal 175

Keywords: Cultural Literacy, Weh-wehan, Generation Z, Prophet's Birthday

\section{Abstraksi}

Tujuan penelitian ini untuk mengenalkan budaya lokal berupa tradisi weh-wehan. Tradisi yang dilakukan menyambut maulid nabi dan berlangsung setahun sekali banyak menarik perhatian. Banyak generasi Z yang terlahir dalam rentang 1995-2010 terdampak dari penggunaan smartphone untuk mengakses berita terkini dan tidak memperhatikan kembali budaya lokal yang ada. Pengaruh ini besar bagi terancamnya literasi budaya yang ditularkan dari gen X kepada kaum generasi Z. Bertujuan untuk mengeatahui literasi budaya yang dilakukan oleh generasi $\mathrm{Z}$ serta dampak tradisi ini kepada generasi Z. Menggunakan deskriptif kualitatif dan snowball sampling, sebagai informan adalah tokoh setempat mewakili generasi $x$ oleh Ketua IPNU, serta gen $\mathrm{Z}$ diwakili oleh ketua karang taruna dan mahasiswa. Berdasar hasil yang didapat bahwa untuk membangun kearifan lokal, dapat mengajak generasi $\mathrm{z}$ untuk berpartisipasi bersama melalui tradisi weh-wehan yang hanya berlangsung setahun sekali dalam perayaan Maulid Nabi. Hal ini bertujuan untuk mengenalkan budaya lintas zaman yang harus tetap dipegang teguh hingga generasi z saat ini.

Kata Kunci: Literasi Budaya, Weh-wehan, Generasi Z, Maulid Nabi

\section{PENDAHULUAN}

Perkembangan dunia literasi saat ini berkembang sangat pesat. Hal ini dapat kita lihat bahwa melalui Pemerintah telah mencanangkan Peraturan Menteri Pendidikan dan Kebudayaan Nomor 23 tahun 2015 tentang Budi Pekerti yang membahas 
tentang Gerakan Literasi Sekolah (GLS) ${ }^{1}$. Saat ini gerakan literasi tidak hanya diakomodir Pemerintah Pusat, masyarakat luas juga sudah membuat gerakan literasi yang diakomodir melalui Pemerintah daerah setempat untuk membuka ruang pada terbukanya gerakan literasi. Gerakan literasi tidak hanya dilakukan di sekolah atau lingkungan akademis, tetapi bisa diterapkan dalam kehidupan sehari-hari. Banyak pelajar saat ini lebih mementingkan permainan daring dibandingkan menggunakan literasi yang dimiliki untuk memperoleh ilmu yang bermanfaat.

Tingkat literasi di Indonesia membuat pelajar tidak memiliki minat untuk membaca dan menulis, salah satu penyebabnya merupakan budaya menonton masyarakat Indonesia yang tinggi. Dari 61 negara, posisi Indonesia berada pada urutan 60 untuk minat membaca yang didasarkan pada studi "Most Littered Nation In The World" yang dilakukan oleh Central Connecticut State University pada 2016. Hanya menduduki satu tingkat lebih tinggi dari negara Botswana, menjadikan Indonesia krisis akses bacaan. Sebesar 28,50\% aspek budaya menjadi salah satu faktor dalam kurangnya literasi ${ }^{2}$. Berbagai macam literasi dapat

\footnotetext{
1 Tempo.co, "Gerakan Literasi Wujudkan Nawa Cita". https://nasional.tempo.co/read/870509/gerakan-literasi-sekolah-wujudkannawa-cita Diakses 31 Oktober 2019

2 Erwin Hutapea. "Literasi Baca Indonesia Rendah, Akses Baca Diduga Jadi Penyebab". https://edukasi.kompas.com/read/2019/06/23/07015701/literasibaca-indonesia-rendah-akses-baca-diduga-jadi-penyebab Diakses 1 November 2019
} 
disalurkan melalui berbagai upaya seperti budaya dalam keseharian yang bisa menjadi suatu kebiasaan jika dilakukan secara berkesinambungan yang tentunya ada peran-peran penting dalam membangun adanya literasi yang baik.

Budaya merupakan kompleks keseluruhan dari pengetahuan, keyakinan, kesenian, moral, hukum, adat istiadat, dan semua kemampuan dan kebiasaan yang lain yang diperoleh seseorang sebagai anggota masyarakat. Dalam hal ini, kebudayaan merupakan segala yang dipelajari dan dialami bersama secara sosial oleh para anggota suatu masyarakat ${ }^{3}$. Bentuk dari sebuah budaya terdiri dalam beberapa unsur antara lain seperti system agama, politik, tradisi, bahasa, pakaian, pakaian, bangunan, karya seni. Dalam keseharian, manusia tidak terlepas dari sebuah bahasa.

Gaya pemahaman setiap generasi memiliki perbedaaan. Pada manusia yang lahir pada 1980-1995 yang disebut generasi Y banyak belajar melalui email, sms dan media sosial. Sedangkan generasi Z merupakan manusia yang lahir pada 1995-2010 lebih banyak menghabiskan waktu melalui gaming, headset, browsing melalui PC (Personal Computer) ${ }^{4}$. Pengaruh gawai saat ini sangat dirasakan banyak orang. Dimulai dengan rendahnya minat baca terhadap buku, beralih menggunakan gawai yang canggih

\footnotetext{
${ }^{3}$ Paul B.Hortory Chester L.Hunt, Sosiologi, Terj. Drs.Aminuddin Ram, M.Ed. Dra.Tita Sobari, Penerbit Erlangga, Jakarta, 1999, Hal. 58

4 Yanuar Surya Putra," Theoritical Review: Teori Perbedaan Generasi".

Among Makarti Vol. 9 No. 18.2016, hal: 130. Homepage :

http://jurnal.stieama.ac.id/index.php/ama/article/viewFile/142/133
} 
membuat budaya menulis dan membaca mulai ditinggalkan. Generasi Z sangat merasakan dampak adanya kecanggihan ini, karena mereka terlahir dimana Internet sudah banyak bermunculan yang bisa mengakibatkan tergusurnya kearifan lokal disekeliling mereka.

Tabel 1. Perbedaan Generasi

\begin{tabular}{|c|c|}
\hline Tahun Kelahiran & Nama Generasi \\
\hline $1925-1946$ & Veteran Generation \\
\hline $1946-1960$ & Baby boom generation \\
\hline $1960-1980$ & X generation \\
\hline $1980-1995$ & Y generation \\
\hline $1995-2010$ & Z generation \\
\hline $2010+$ & Alfa generation \\
\hline
\end{tabular}

Generasi $\mathrm{Z}$ identik dengan generasi yang menyukai teknologi, fleksibel, lebih cerdas dan toleran pada perbedaan budaya. Pola pikir generasi $\mathrm{Z}$ yang terbuka dan menerima perbedaan disisi lain membuat mereka kesulitan mendefinisikan dirinya sendiri. Pada generasi $\mathrm{Z}$, menggunakan selebgram sebagaimana pembelajaran dalam mendifinisikan diri mereka ${ }^{5}$. Menurut Toronto kecenderungan generasi $\mathrm{Z}$ dalam memanfaatkan teknologi untuk menghindari perjuangan di kehidupan offline mereka serta bertujuan untuk mencari kenyamanan dengan melarikan diri dan berfantasi untuk mengisi

\footnotetext{
${ }^{5}$ Ranny Rastati. Media Literasi bagi Digital Natives: Perspektif Generasi Z di Jakarta. Jurnal Teknologi Pendidikan Vol. 06. 2018. Hal: 63. Homepage : http://dx.doi.org/10.31800/jtp.kw.v6n1.p60--73
} 
waktu maupun kekosongan emosional ${ }^{6}$. Efek ini menimbulkan tidak nyaman pada generasi $\mathrm{Z}$ terhadap dunia sekeliling mereka. Komunitas setempat yang dapat memperbaiki dampak buruk bagi generasi Z, karena komunitas lokal mempunyai peranan kuat setelah adanya peran positif dari orang tua.

Tradisi dalam Bahasa Latin "traditio" yang artinya "diteruskan" dan "kebiasaan". Dalam arti sederhana, tradisi merupakan segala hal yang dilakukan sejak lama dan menjadi bagian serta kebiasaan dalam kehidupan pada kelompok masyarakat, biasanya dari suatu negara, kebudayaan, agama dan waktu yang sama. Tradisi Jawa hingga saat ini yang masih banyak ditemukan khususnya di Kecamatan Kaliwungu, Kabupaten Kendal diantaranya tradisi syawalan, tradisi ziarah, mitoni, dug-deran, weh-wehan. Hal mendasar pada sebuah tradisi adalah penyampaian informasi secara tertulis ataupun lisan yang dilakukan dari generasi ke generasi ${ }^{7}$.

Perayaan maulid Nabi Muhammad SAW merupakan perayaan untuk seluruh umat Islam. Perbedaan cara perayaan disesuaikan dengan kearifan lokal daerah setempat. Maulid Nabi yang berarti hari kelahiran Nabi Muhammad SAW yang tepat pada 12 Rabi'ul awal. Dalam setiap perayaan bulan maulud

\footnotetext{
' Selma Kirana Haryadi," Darurat Kesehatan Mental Generasi Z". https://muda.kompas.id/baca/2019/04/12/darurat-kesehatan-mental-generasi-z/ diakses 2 November 2019

${ }^{7}$ Waqi'Aturrohmah, Tradisi Weh-wehan dalam Memperingati Maulid Nabi Muhammad SAW dan Implikasinya terhadap Ukhuwah Islämiyah di Kecamatan Kaliwungu kabupaten Kendal, UIN Walisongo, Semarang, 2015, Hal. 2
} 
(bulan dalam hitungan Jawa) umat Islam akan merayakan maulid nabi. Kumandang shalawat yang disiarkan dari musola dan masjid diramaikan oleh anak kecil hingga orang tua untuk bersama-sama membaca kitab ndibak dan berjanjen. Warga NU sangat erat dalam peringatan hari kelahiran Nabi Muhammad. Perayaan ini bersifat luapan rasa syukur, kegembiraan serta penghormatan terhadap lahirnya Nabi Muhammad dan perjuangan yang telah dilakukan dalam menegakkan Agama Islam $^{8}$.

Dalam merayakan kegembiraan, disesuaikan dengan tradisi lokal di masing-masing daerah. Yang biasa dilakukan adalah berbagi hidangan spesial kepada kerabat terdekat seperti tetangga sekitar, hingga menyelenggarakan upacara seperti doa bersama di rumah masing-masing hingga ada yang di mushola atau masjid dan ada yang menyelenggarakan secara besar-besaran dengan dihadiri ribuan umat Islam ${ }^{9}$. Seperti halnya weh-wehan yang diambil dari bahasa Jawa yakni aweh yang berarti sehingga arti weh-wehan yakni saling memberi. Tradisi ini diikuti dari orang tua hingga terutama anak-anak yang akan saling berkunjung dari satu rumah ke rumah yang lain untuk mengumpulkan beraneka ragam jajan dan makanan. ${ }^{10}$ Perumusan masalah dalam penelitian

\footnotetext{
${ }^{8}$ Al-Habib Zainal Abidin bin Ibrahim bin Smith al-Alawi al-Husaini, Tanya Jawab Aqidah Ahlusunnah wal Jamaah, Kalista, Surabaya, 2009. h. 157-159

${ }^{9}$ H. Munawir Abdul Fatah, Tradisi Orang-orang NU, Pustaka Pesantren, Yogyakarta, 2006, h. 293

${ }^{10}$ Metropos.id. "Tradisi Weh - wehan di Kaliwungu - Kendal masih di lestarikan jelang Maulid Nabi”. https://www.metropos.id/2019/11/09/tradisi-
} 
ini adalah bagaimana membangun literasi budaya pada generasi $\mathrm{Z}$ dan apa saja dampak tradisi weh-wehan pada generasi Z

\section{TINJAUAN PUSTAKA}

\section{A. Literatur Review}

Pada penelitian ini mendapatkan kajian pustaka bahwa generasi $\mathrm{Z}$ merupakan generasi yang mengagumi internet. Pada generasi ini pula tingkat stres sudah mulai dinampakkan, karena sedari bayi para orang tua sibuk diajak ke berbagai les seperti les merangkak, les berhitung, les bahasa Inggris. Interaksi-interaksi sosial yang dialami generasi $\mathrm{Z}$ banyak terhubung melalui dunia nyata serta virtual. Dalam penyampaian literasi akan lebih mudah dipahami jika melalui video yang viral di media sosial seperti Instagram, Line, Facebook ${ }^{11}$.

Karakteristik generasi $\mathrm{Z}$ berbeda dengan generasi yang lain, perbedaan ini nampak pada penguasaan informasi dan teknologi. Bagi generasi $\mathrm{Z}$ internet sudah menjadi budaya global sehingga hal itu berpengaruh pada nilai-nilai, pandangan dan tujuan hidup bagi generasi Z. Beda pula dengan generasi $\mathrm{Y}$, dimana generasi ini mempunyai karakteristik dimana ia dibesarkan, status ekonomi, serta sosial keluarga. Generasi Y lahir pada era internet booming, karena pada generasi ini lebih banyak menggunakan

\footnotetext{
weh-wehan-di-kaliwungu-kendal-masih-di-lestarikan-jelang-maulid-nabi/ diakses 2 November 2019

${ }^{11}$ Ranny Rastati. ibid
} 
teknologi instan seperti SMS, instan messaging, dan media sosial seperti facebook dan twitter $^{12}$.

Kemampuan generasi $\mathrm{Z}$ dalam mengoperasikan komputer seolah menjadi sahabat mereka. Keingintahuan mereka sangat besar terhadap hal-hal yang terkait dengan sesuatu disekitar mereka. Selain itu mereka dikenal sangat native and technologically terhadap bermacam-macam perangkat elektronik yang modern, mudah beradaptasi, dan mampu mengeksplorasi hal-hal yang ada didalamnya. Generasi $\mathrm{Z}$ lebih banyak menghabiskan waktunya didalam rumah dengan bermain gadget, mereka menganggap lingkungan yang ada disekitar mereka bukanlah hal yang menarik bagi mereka. Karena bagi mereka pertemuan tidak harus berada dalam suatu ruang berbentuk fisik, dunia maya adalah ruang mereka yang sesungguhnya ${ }^{13}$.

Dalam membangun kearifan lokal diperlukan dukungan dari masyarakat sekitar. Perlu dikenalkannya simbol-simbol kearifan sosial yang ada, karena melalui cara ini dirasa lebih efektif dalam proses membangun kearifan lokal. Terlebih lagi diadakannya pendampingan untuk mengetahui kemajuan dan kesulitan yang dihadapi, dengan pendampingan dapat berdampak pada kemajuan yang dicapai serta kesulitan apa yang dialami. Sarana dan prasarana tidak kalah penting dalam membangun kearifan lokal,

\footnotetext{
12 Yanuar Surya Putra. ibid

13 John Fredy dan Bobby Saragih. Fenomena Bermain Generasi Z dan Hubungannya dengan Eksistensi Ruang Bermain Terbuka di Lingkungan Perumahan Sederhana. Jurnal Comtech Vol. 3 No. 1. 2012. Hal: 8-14
} 
dukungan ini bisa berupa fisik dan non fisik lebih mana yang dibutuhkan ${ }^{14}$.

\section{B. Kerangka Teori}

Literasi secara umum mengacu pada kemampuan membaca dan menulis artinya seorang literat merupakan orang yang menguasai keterampilam membaca dan menulis, bahkan kemampuan berbahasa mendahului kedua keterampilan tersebut dari sudut kemudahan dan penguasaannya adalah kemampuan menyimak dan berbicara. ${ }^{15}$

Proses literasi merupakan aspek penting yang wajib dimiliki oleh setiap pembelajar. Ketika berbicara mengenai bahasa, tidak lepas dari pembicaraan tentang budaya karena bahasa bagian dari sebuah budaya. Pendefinisian literasi harus bisa mencakup unsurunsur tentang bahasa itu sendiri, yakni situasi sosial budayanya. Didalam literasi terdapat tingkatan-tingkatan yang menanjak. Apabila seseorang dapat menguasai satu tahapan literasi maka akan memiliki pijakan untuk naik ke tingkatan berikutnyya. Terdapat empat tingkatan literasi: performative, functional, informational, dan epistemic. Tingkat literasi performatif, orang hanya mampu membaca dan menulis, serta berbicara

\footnotetext{
14 Thesi Rismayanti Siti Rohmah. Membangun Kearifan Lokal melalui Gerakan Literasi Mibanda (Micinta Baca Tulis Aksara Sunda) di SDN Sukahayu Kabupaten Subang. Jurnal Dinamika Pendidikan Dasar Vol. 10. No. 2. 2018. Hal: 59-73

15 Lizamudin Ma'mur, Membangun Budaya Literasi, (Jakarta: diadit Media 2010) hal 111.
} 
menggunakan simbol-simbol yang dipakai (bahasa). Tingkat functional, setiap orang diharapkan mampu menggunakan bahasa untuk digunakan dalam keseharian seperti membaca buku. Pada tingkatan informational, setiap orang diharapkan mampu menjelajah pengetahuan menggunakan bahasa. Sementara ditingkat epistemic, orang diharapkan dapat menggunakan bahasa untuk mentransformasikan pengetahuan ${ }^{16}$.

Kebudayaan bersifat universal serta dapat ditemukan disemua kebudayaan bangsa yang tersebar di seluruh penjuru dunia. Sistem bahasa merupakan unsur kebudayaan yang dibutuhkan untuk memenuhi kebutuhan sosialnya dalam berinteraksi dan berhubungan dengan sesamanya. Sistem pengetahuan dalam kebudayaan berkaitan dengan sistem peralatan hidup dan teknologi, karena sistem pengetahuan bersifat abstrak dan berwujud didalam ide manusia. Sistem sosial adalah unsur budaya berupa sistem kekerabatan dan organisasi sosial. Dalam sistem sosial, yang paling dekat dengan manusia adalah keluarga inti. Manusia selalu mempertahankan hidup dengan berusaha membuat peralatan dan benda-benda yang kemudian masuk dalam unsur sistem peralatan hidup dan teknologi. Disisi lain sebuah mata pencaharian hidup menjadi unsur etnografi dalam unsur kebudayaan. Sistem religi merupakan asal mula permasalahan dalam masyarakat karena terdapat pertanyaan

\footnotetext{
${ }^{16}$ Faizin.2018. Literasi Budaya Lokal untuk Meminimalisir Gegar Budaya Pemelajar Bipa. Prosiding Senasbasa. Hal: 116-124. Homepage: http://research-report.umm.ac.id/index.php/SENASBASA
} 
mengapa manusia percaya kepada suatu kekuatan gaib atau supranatural dibanding manusia. Yang terakhir adalah kesenian, unsur seni bisa berupa tari-tarian, patung, ukiran, dan hiasan ${ }^{17}$.

Sebuah kebudayaan memiliki hasil yang mana semua hasil karya, rasa dan cipta masyarakat. Karya masyarakat dapat menghasilkan sebuah teknologi dan kebudayaan kebendaaan atau kebudayaan jasmaniah diperlukan oleh manusia untuk menguasai alam sekitar agar kekuatan serta hasilnya dapat diabadikan untuk keperluan masyarakat ${ }^{18}$.

Definisi generasi dalam beberapa tahun ini telah berkembang. Generasi merupakan sekelompok individu yang mengidentifikasi kelompoknya berdasar kesamaan lokasi, umur, tahun kelahiran, dan kejadian-kejadian dalam kehidupan kelompok individu yang mempunyai pengaruh signifikan dalam fase pertumbuhan mereka. Terdapat dua hal utama dalam pengelempokan generasi, yaitu faktor demografi terdapatnya kesamaan tahun kelahiran dan yang kedua merupakan faktor sosiologis khususnya adalah kejadian historis ${ }^{19}$.

Generasi $\mathrm{Y}$ biasa dikenal dengan generasi milenium, pada generasi ini lebih banyak menggunakan komunikasi instan seperti

\footnotetext{
${ }^{17}$ Tasmuji, Dkk, Ilmu Alamiah Dasar, Ilmu Sosial Dasar, Ilmu Budaya Dasar, (Surabaya: IAIN Sunan Ampel Press, 2011), 160-165. Lihat pula Jacobus Ranjabar, Sistem Sosial Budaya Indonesia; Suatu Pengantar (Bogor: Ghalia Indonesia, 2006) 20 - 23

18 Jacobus Ranjabar, Sistem Sosial Budaya Indonesia; Suatu Pengantar (Bogor : GHalia Indonesia, 2006) 21

${ }^{19}$ Yanuar Surya Putra. ibid
} 
email, sms, instan messaging, serta media sosial seperti twitter dan facebook. Generasi ini sangat terbuka pada komunikasi dibanding generasi sebelumnya serta kehidupannya berpengaruh pada teknologi. Reaktif pada perubahan lingkungan dan perhatian pada kekayaan. Beda halnya dengan generasi Z, pada generasi ini mampu menyatukan kegiatan dalam satu waktu (multi tasking). Terlihat saat generasi ini menjalankan media sosial menggunakan ponsel, berselancar di dunia internet menggunakan PC diiringi musik menggunakan headset. Kebanyakan yang dilakukan oleh generasi $\mathrm{Z}$ terfokus pada dunia maya. Generasi $\mathrm{Z}$ biasa disebut dengan iGeneration atau generasi internet, dimana teknologi dan internet adalah bagian dari hidup. Budaya global yang ada menjadikan internet sebagai pengaruh nilai-nilai, pandangan serta tujuan hidup mereka. Karena mereka sedari kecil bersahabat dengan gadget secara tidak langsung berpengaruh pada kepribadian $^{20}$.

\section{METODOLOGI PENELITIAN}

Penelitian ini dilaksanakan di Kecamatan Kaliwungu, Kabupaten Kendal pada 3 November 2019 hingga 10 November 2019. Menggunakan metode kualitatif, merupakan penelitian yang menghasilkan data deskriptif secara tertulis ataupun lisan dari orang serta perilaku yang diamati. Tidak diperbolehkan

${ }^{20}$ Ibid, hlm: 129-130 
adanya isolasi invidu atau kelompok kedalam variabel atau hipotesis, tetapi harus dipandang sebagai satu keutuhan ${ }^{21}$.

Sumber data primer generasi $\mathrm{Z}$ masyarakat yakni ketua karang taruna, pelajar/mahasiswa, dengan dilengkapi data sekunder generasi $\mathrm{Y}$ yang merupakan Ketua IPNU Kabupaten Kendal. Menggunakan teknik snowball sampling merupakan teknik pengambilan sumber data yang diawal jumlahnya sedikit belum memenuhi data yang lengkap, maka harus mencari orang lain sebagai sumber data $^{22}$. Dengan cara peneliti memilih informan tertentu sesuai pertimbangan yang akan memberikan data yang diperlukan, selanjutnya berdasar data yang diperoleh dari sampel sebelumnya peneliti menetapkan sampel lain untuk memberikan data yang lengkap. Analisis dari setiap hasil akan disamakan untuk mencari informasi terbaru dan disertai bukti pendukung seperti gambar.

\section{PEMBAHASAN}

\section{Membangun Literasi pada Generasi Z}

Dunia digital mengubah cara pandang konvensional menjadi hal yang lebih praktis. Distribusi internet yang terus tumbuh menjadikan semua informasi dapat lebih cepat didapatkan. Generasi Z yang lahir pada 1995-2010 sangat akrab dengan dunia

\footnotetext{
${ }^{21}$ Lexy J. Moleong, Metodelogi Penelitian Kualitatif, (Bandung: PT. Remaja Rosdakarya 2002), hlm. 4

22 Sugiyono, Metode Penelitian Kuantitatif Kualitatif dan R\&D, (Bandung: Alfabeta, 2008), 300
} 
internet, dimana semua informasi terasa cepat. Keakraban pada gadget membuat generasi ini terbiasa melakukan berbagai kegiatan dalam satu waktu, seperti menulis di aplikasi pengolah kata di ponsel sembari mendengarkan musik melalui headset dalam satu waktu. Para generasi Z di Kecamatan Kaliwungu menghabiskan waktu kurang lebih 5 jam disaat hari biasa atau lebih dari itu ketika di hari libur untuk berselancar menggunakan gadget mereka. Mahasiswa yang berdomisili di kampung setempat juga mengatakan dalam sehari lebih banyak menghabiskan waktu untuk menjelajah dunia melalui gawai mereka, terutama dalam hal membaca mereka mulai meninggalkan buku cetak. Dalam menulis, aplikasi catatan di handphone lebih mengesankan dibanding menulis di buku tulis. Bagi mereka menulis aplikasi catatan di handphone lebih praktis dan tidak memerlukan banyak peralatan.

Velani (20) selaku Ketua Karang Taruna, di kecamatan Kaliwungu sudah tersebar titik untuk bermain wifi gratis. Kesempatan ini banyak dimanfaatkan pemuda untuk mencari informasi hingga bermain game online. Rata-rata pemuda yang bermain internet didominasi pelajar/ mahasiswa untuk mencari informasi yang dibutuhkan. Tidak hanya informasi, mereka banyak mendapatkan berita terbaru dari sosial media bisa berupa foto ataupun video. Kegemaran mereka mengabadikan suatu perayaan menjadikan mereka banyak belajar secara mandiri yang 
secara tidak langsung menjadikan generasi $\mathrm{Z}$ ini banyak mengetahui informasi secara cepat dibanding generasi $\mathrm{Y}$.

Tradisi weh-wehan yang biasa dilakukan pada peringatan maulud nabi khususnya di kecamatan Kaliwungu, Kabupaten Kendal. Menurut Maskun (28), ketua IPNU Kendal, nama wehwehan sendiri diambil dari bahasa Jawa yang dalam bahasa Indonesia bermakna saling memberi. Kegiatan dalam wehwehan ditekankan lebih banyak untuk saling berbagi yang isinya berupa makanan. Kemeriahan dalam acara ini adalah orang tua meminta tolong kepada anak untuk mengunjungi tetangga terdekatnya dengan barter makanan apa yang dipunya. Makanan ini dulunya masih berupa jajanan tradisional, seiring perkembangan zaman banyak masyarakat lebih memilih jajanan modern dibanding jajan tradisional. Makanan khas ketika acara ini berlangsung adalah sumpil. Merupakan makanan khas Kaliwungu yang berbahan dasar dari beras.

Banyaknya pemuda-pemudi mengikuti tradisi weh-wehan, menjadikan generasi $\mathrm{Z}$ enggan untuk keluar rumah. Tantangan digital yang dihadapi membuat tradisi ini bisa berlalu dengan sekejap dan bisa diulangi dengan sebuah dokumentasi di gadget. Salah satunya Estie (21) menganggap weh-wehan terjadi tiap tahun, jika ada hal yang semua bisa dilakukan di rumah kenapa harus diluar. Karena tradisi ini hanya setahun sekali di Kaliwungu, sehingga para orang tua mengharuskan anak mereka ikut serta dalam perayaan. Banyak diantara mereka lebih sibuk 
dalam mengabadikan tradisi ini atau sekedar update status di media sosial mereka.

Gambar 1. Status di media sosial

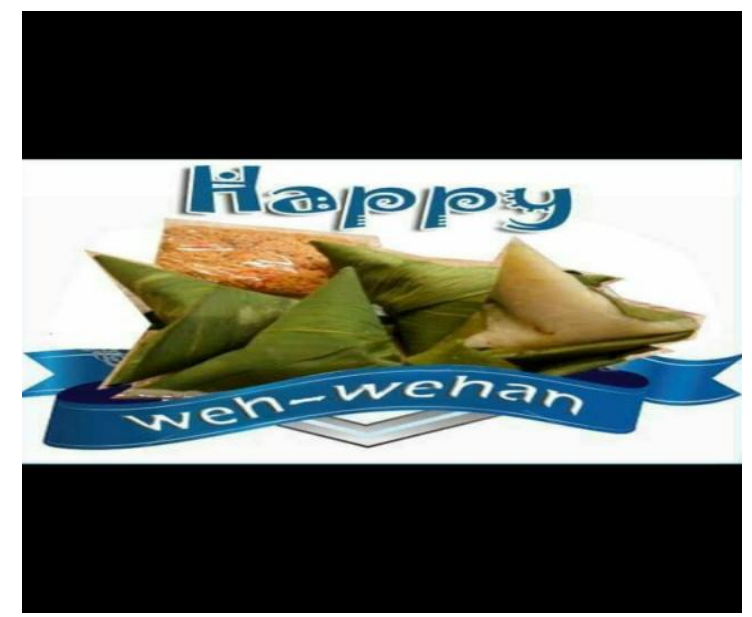

Penyampaian literasi budaya pada generasi $\mathrm{Z}$ tetap didampingi oleh generasi sebelumnya yakni generasi Y. Ketua IPNU Kendal, selalu memberikan ajakan untuk bermedia sosial yang santun dan mengenalkan budaya lokal kepada orang lain. Selama ini generasi $\mathrm{Z}$ yang disebut iGeneration lebih banyak berhubungan dengan dunia internet, dan generasi $\mathrm{Z}$ di Kaliwungu menganggap dengan update status di media sosial berarti mereka dianggap ada. Dengan adanya tradisi weh-wehan di Kaliwungu membuat Estie \& Velani merasa ada bahan untuk bermedia sosial karena tradisi ini tidak ada di tempat lain. Di sisi lain mereka mengenal tradisi, mereka juga berliterasi menggunakan media sosial agar tidak dianggap sepenuhnya menjadi orang yang anti sosial di lingkungan masyarakat. 
Bagi generasi Z, weh-wehan ini bukan menjadi ajang yang mempersulit dunia mereka dalam memanfaatkan teknologi. Justru dengan adanya generasi $\mathrm{Z}$, weh-wehan semakin dikenal masyarakat luas. Banyaknya yang mengabadikan dan muncul diberbagai media berita online membuat tradisi ini semakin dikenal masyarakat luas. Bagi generasi $\mathrm{Z}$ yang multitasking, tidak masalah jika suatu budaya atau tradisi harus berkembang beriringan dengan majunya teknologi. Karena dengan teknologi, suatu budaya atau tradisi makin banyak dikenal oleh masyarakat luas.

\section{KESIMPULAN DAN SARAN}

Generasi $\mathrm{Z}$ sebagai generasi yang banyak meghabiskan waktu dengan internet mengharuskan mereka menyimpan waktu lebih lama untuk diri sendiri. Dengan adanya tradisi weh-wehan membuat generasi ini belajar cara berkomunikasi dengan orang lain untuk melestarikan tradisi yang ada disekitar mereka. Tradisi yang sudah ada terlebih dahulu sebelum generasi $\mathrm{Z}$, membuat mereka harus menyesuaikan agar tradisi tidak menghambat dunia digital mereka. Penggabungan tradisi dan teknologi membuat generasi $\mathrm{Z}$ tidak lupa budaya yang sudah ada.

Saran peneliti, tradisi weh-wehan tetap menjaga keaslian yang sudah diajarkan oleh generasi sebelumnya. Melibatkan generasi $\mathrm{Z}$ lebih baik untuk dibuat sesering mungkin, dengan begitu tradisi weh-wehan banyak dikenal orang yang berdampak 
PROMEDIA (PUBLIC RELATION DAN MEDIA KOMUNIKASI) ISSN 2460-9633

Volume Ke-6 No. 1, 2020, Saputra, Membangun Literasi, hal 155 - hal 175

pada potensi wisata lokal kedepannya. Adanya wisata lokal akan menjadi ladang untuk masyarakat sekitar dalam menggarap tradisi yang ada turun-temurun di Kaliwungu. 


\section{DAFTAR PUSTAKA}

Al-Husaini, Al-Habib Zainal Abidin bin Ibrahim bin Smith alAlawi. 2009. Tanya Jawab Aqidah Ahlusunnah wal Jamaah. Kalista, Surabaya.

Co.Tempo. 2019. "Gerakan Literasi Wujudkan Nawa Cita". https://nasional.tempo.co/read/870509/gerakan-literasisekolah-wujudkan-nawa-cita Diakses 31 Oktober.

Faizin. 2018. Literasi Budaya Lokal untuk Meminimalisir Gegar Budaya Pemelajar Bipa. Prosiding Senasbasa. Homepage: http://research-report.umm.ac.id/index.php/SENASBASA

Fatah, H. Munawir Abdul. 2006. Tradisi Orang-orang NU. Pustaka Pesantren, Yogyakarta.

Fredy, John dan Bobby Saragih. 2012. Fenomena Bermain Generasi $Z$ dan Hubungannya dengan Eksistensi Ruang Bermain Terbuka di Lingkungan Perumahan Sederhana. Jurnal Comtech Vol. 3 No. 1

Gustini, Neng. 2016. Budaya Literasi (Model Pengembangan Budaya Baca Tulis Berbasis Kecerdasan Majemuk Melalui Tutor Sebaya). Yogyakarta: deepublish.

http://www.republika.co.id/berita/koran/didaktika/14/12/15

Haryadi, Selma Kirana. 2019.'Darurat Kesehatan Mental Generasi Z'.

https://muda.kompas.id/baca/2019/04/12/darurat-kesehatanmental-generasi-z/ diakses 2 November 2019

Hutapea, Erwin. 2019. "Literasi Baca Indonesia Rendah, Akses Baca Diduga Jadi Penyebab".

https://edukasi.kompas.com/read/2019

/06/23/07015701/literasi-baca-indonesia-rendah-akses-bacadiduga-jadi-penyebab Diakses 1 November 2019

L.Hunt, Paul B.Hortory Chester. 1999. Sosiologi, Terj. Drs.Aminuddin Ram, M.Ed. Dra.Tita Sobari, Penerbit Erlangga, Jakarta.

Ma'mur, Lizamudin. 2010. Membangun Budaya Literasi, Jakarta: diedit Media.

Metropos.id. 2019. "Tradisi Weh-wehan di Kaliwungu-Kendal masih di lestarikan jelang Maulid Nabi". 
https://www.metropos.id/2019/11/09/tradisi-weh-wehan-dikaliwungu-kendal-masih-di-lestarikan-jelang-maulid-nabi/ diakses 2 November.

Moleong, Lexy J. 2002. Metodelogi Penelitian Kualitatif. Bandung: PT. Remaja Rosdakarya.

Putra, Yanuar Surya. 2016." Theoritical Review: Teori Perbedaan Generasi”. Among Makarti Vol. 9 No. 18.

http://jurnal.stieama.ac.id/index.php/ama/article/viewFile/14 $2 / 133$

Ranjabar, Jacobus. 2006. Sistem Sosial Budaya Indonesia; Suatu Pengantar. Bogor: Ghalia Indonesia.

Rastati, Ranny. 2018. Media Literasi bagi Digital Natives: Perspektif Generasi Z di Jakarta. Jurnal Teknologi Pendidikan Vol. 06. Hal: 63.

http://dx.doi.org/10.31800/jtp.kw.v6n1.p60--73

Rismayanti, Thesi Siti Rohmah. 2018. Membangun Kearifan Lokal Melalui Gerakan Literasi Mibanda (Micinta Baca Tulis Aksara Sunda) Di Sdn Sukahayu Kabupaten Subang. Jurnal Dinamika Pendidikan Dasar Vol. 10, No. 2.

Sugiyono. 2008. Metode Penelitian Kuantitatif Kualitatif dan $R \& D$, Bandung: Alfabeta.

Tasmuji, Dkk, 2011. Ilmu Alamiah Dasar, Ilmu Sosial Dasar, Ilmu Budaya Dasar. Surabaya: IAIN Sunan Ampel Press.

Waqi'aturohmah. 2015. Tradisi Weh-Wehan Dalam Memperingati Maulid Nabi Muhammad SAW dan Implikasinya Terhadap Ukhuwah Islamiyah Di Kecamatan Kaliwungu Kabupaten Kendal.UIN Walisongo, Semarang. 